\title{
Malignant Leydig Cell Tumor with Spindle-Shaped Cells in a Male CD-1 Mouse
}

\author{
Aya OHNUMA ${ }^{1)}$, Toshinori YOSHIDA ${ }^{1) *}$, Naofumi TAKAHASHI ${ }^{1)}$, Satoshi AKEMA ${ }^{1)}$, Mutsumi KUMAGAI ${ }^{1}$, \\ Yuko CHIBA $^{1)}$, Yukiko KASHIMOTO ${ }^{1)}$, Maki KUWAHARA ${ }^{1)}$, Nobuaki NAKASHIMA ${ }^{1)}$ and Takanori HARADA ${ }^{1)}$

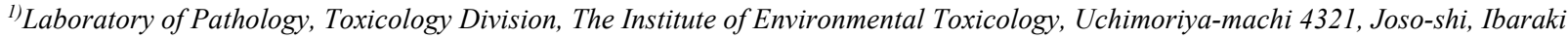 \\ 303-0043, Japan
}

(Received 2 November 2009/Accepted 22 December 2009/Published online in J-STAGE 15 January 2010)

ABSTRACT. Leydig cell tumors with spindle-shaped cells are very rare in humans and animals. We report that an 84-week-old male CD1 mouse had a malignant Leydig cell tumor characterized by proliferation of oval to spindle-shaped cells with or without fat deposition, and with a storiform pattern. These cells were immunopositive for inhibin and S-100, and negative for the androgen receptor, thereby suggesting that they may have differentiated from Leydig cells. This differentiation from Leydig cells was further confirmed by the immunopositivity of these cells for nestin and $\alpha$-smooth muscle actin, both of which are known to be expressed in the stem/progenitor cells that differentiate into Leydig cells. These findings suggest that the tumor is most probably a malignant spindle-cell-type Leydig cell tumor.

KEY WORDS: $\alpha$-smooth muscle actin, inhibin, Leydig cell, nestin, testis.

Leydig cell tumors are a type of sex cord-gonadal stromal tumors (SCSTs), and are frequently observed in Fischer rats, but rarely observed in other rat strains, other animals, and humans. The tumor shows various histologic features that are characteristic of those observed during the evolution of Leydig cells [12]. The most common type of Leydig cell tumor consists of medium to large polygonal cells with an eosinophilic cytoplasm and distinct lipid deposits, which are characteristic features of normal Leydig cells [8, 12, 19]. Leydig cell tumors containing spindle-shaped cells have rarely been reported in humans; further, if the spindle-cell component was prominent in such tumors, they were regarded as incompletely differentiated (unclassified) SCSTs according to the WHO classification [12]. Here, we report a malignant spindle-cell-type Leydig cell tumor that is positive for nestin and $\alpha$-smooth muscle actin (aSMA) in an aging male mouse. We believe that this tumor is distinct from the incompletely differentiated SCSTs.

The affected animal was an 84-week-old male Crlj:CD1(ICR) mouse (Charles River Japan Inc., Kanagawa, Japan) that had been allocated to the experimental group in a 1.5year-long carcinogenicity study of a chemical. During the study, the mouse was handled in accordance with the Guidelines for Animal Experimentation issued by the Japanese Association for Laboratory Animal Science [7]. The mouse developed a subcutaneous lesion in the genital region 1 week before terminal sacrifice. The mouse was deeply anesthetized with ether and then killed by exsanguination at the end of the study. Necropsy revealed the presence of a brownish-colored neoplastic mass, $20 \times 15 \times 15 \mathrm{~mm}$ in size, on the right side of the testis. The cut surface was firm and either white or brown in color, and contained small areas

\footnotetext{
* Correspondence to: Yoshida, T., Laboratory of Pathology, Toxicology Division, Institute of Environmental Toxicology, Uchimoriya-machi 4321, Joso, Ibaraki 303-0043, Japan.

e-mail: yoshida@iet.or.jp
}

with necrosis and hemorrhage. The neoplastic mass was fixed in $10 \%$ neutral buffered formalin and embedded in paraffin. The paraffin sections $(5 \mu \mathrm{m})$ were stained with hematoxylin and eosin (H\&E). Additional sections were stained with Masson's trichrome or with periodic acidSchiff (PAS) with or without diastase treatment. In addition, $8-\mu \mathrm{m}$ frozen sections of the neoplastic mass were stained with oil-red-O. Immunohistochemical analysis was performed using the Dako EnVision kit (Dako, Glostrup, Denmark). Additionally, paraffin sections were incubated with one of the following primary antibodies: anti-pig vimentin monoclonal antibody (V9), anti-cow S-100 protein polyclonal antibody, anti-human inhibin $\beta$ A polyclonal antibody, anti-rat androgen receptor (AR) polyclonal antibody (epitope specific), or anti-rat nestin polyclonal antibody. We also used a horseradish peroxidase-labeled anti-human aSMA monoclonal antibody (1A4). The primary antibodies for inhibin, AR, and nestin were obtained from Thermo Fisher Scientific (Fermont, CA, U.S.A.), ProteinTech Group Inc (Chicago, IL, U.S.A.), and Millipore Corporation (Billerica, MA, U.S.A.), respectively, whereas the other antibodies were obtained from Dako. For antigen retrieval, sections were pretreated with sodium citrate buffer $(0.1 \mathrm{M}$, $\mathrm{pH}$ 6.0) in an autoclave at $120^{\circ} \mathrm{C}$ for $5 \mathrm{~min}$. The immunohistochemical products were visualized using the substrate 3,3'-diaminobenzidine and were counterstained with hematoxylin. We used formalin-fixed, paraffin-embedded sections of a pair of testes from an age-matched control mouse or of the brain from a 3-week-old mouse as controls for immunostaining.

Under the microscope, the neoplastic mass appeared to be sharply circumscribed with connective-tissue capsules (stained with Masson's trichrome). The neoplasm was composed of vacuolated or foamy (oil-red-O-positive) cells in the peripheral region (Fig. 1A). The central region consisted of oval to spindle-shaped cells that were sometimes 


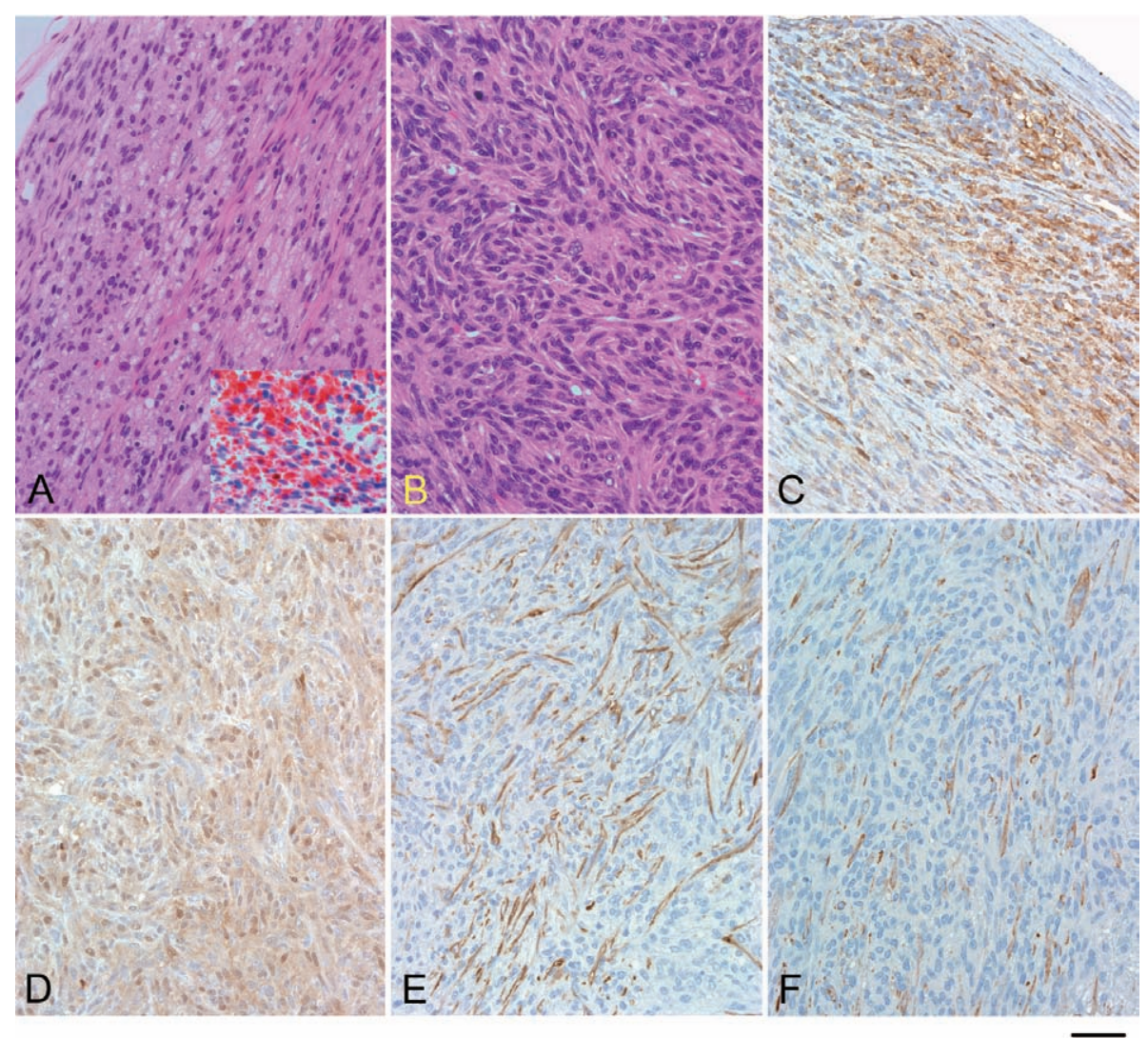

Fig. 1. Histological and immunohistochemical features of the tumor cells. (A) Vacuolated or foamy cells with oval to spindle-shaped nuclei were observed in the peripheral region of the tumor mass. Hematoxylin and eosin (H\&E) staining. Inset: Oil-red-O-positive lipid deposits in the tumor cells. (B) The tumor cells appeared to be arranged in a storiform pattern. H\&E staining. (C-F) The tumor cells were immunopositive for inhibin (C), S-100 (D), aSMA (E), and nestin (F). Bar $=20 \mu \mathrm{m}$.

arranged in fascicles or in a storiform pattern (Fig. 1B); these fascicles closely mimicked those observed in leiomyosarcomas. The tumor cells showed nuclear atypia, including variability in nuclear size and shape, and frequent mitoses. The tumor cells also showed local invasion into the capsules, and the tumor mass included hemorrhagic and necrotic foci that were surrounded by pseudopalisade tumor cells. The tumor was entirely depleted of normal seminal tubules, even though there were a few atrophic seminal tubules containing hypertrophic Sertoli cells. These findings suggest that the tumors were malignant although there was no evidence of any metastasis or invasion of the blood vessels or lymph nodes.

In immunohistochemical analysis, vacuolated or foamy tumor cells were found to be strongly positive for inhibin (Fig. 1C) and S-100 (Fig. 1D), whereas oval to spindleshaped cells were only weakly positive for these proteins. Both vacuolated and foamy tumors cells were positive for vimentin, and certain leiomyosarcomatous spindle cells were strongly positive for aSMA (Fig. 1E). Interestingly, a few spindle-shaped tumor cells were also positive for nestin (Fig. 1F). In the tumor mass, there was a very small popula- tion of eosinophilic globule cells with characteristic prominent cytoplasmic granules; these granules were positive for the PAS reaction with or without diastase treatment. The Sertoli cells in the atrophic seminal tubules were positive for both inhibin and AR. Leydig cells in the testes of the agematched control mouse were positive for inhibin, and Sertoli cells were positive for inhibin and AR. aSMA-positive cells were recognized close to seminiferous tubules and tunica albuginea and also found in intertubular blood vessel walls. The brain tissue of the immature control mouse, but not the testes of the age-matched control mouse, was confirmed to be positive for nestin.

Because of spindle-cell growth, the tumor in our mouse did not have the appearance of a typical Leydig cell tumor. The sarcomatoid region had random fascicular and storiform arrangements with necrotic or hemorrhagic foci, and exhibited high mitotic activity, nuclear atypia, and local invasion of the capsules, as previously described for human Leydig cell tumors with spindle-shaped cells [17]. The immunohistochemical features of the tumor in our case were partly similar to those of Leydig cell tumors with spindleshaped cells, which are also positive for inhibin, S-100, and 
vimentin [3]. However, human Leydig cell tumors with spindle-shaped cells are generally negative for aSMA [17]. Therefore, we considered another type of spindle-celled tumor, i.e., incompletely differentiated SCST, which is characterized by immunopositivity for inhibin, melan-A, S100 , and aSMA $[10,14]$. Incompletely differentiated SCST cells, which can differentiate into granulosa cells, are strongly positive for aSMA. In our case, however, only typical spindle-shaped cells in the tumor were positive for both aSMA and inhibin, and these cells showed no evidence of differentiation to granulosa cells, thereby implying that spindle-shaped tumor cells and Leydig cells have the same lineage.

The stem, precursor, and progenitor cells of Leydig cells have been recently isolated from the testes of rats. These cells are basically spindle shaped and negative or positive for the differentiation marker $3 \beta$-hydroxysteroid dehydrogenase ( $3 \beta$-HSD) [5], and are found close to either the seminiferous tubules or the blood vessels [15], both of which are positive for aSMA. The progenitors of spindle to ovalshaped cells differentiate into hypertrophic fetal-type Leydig cells $[5,16]$. Davidoff et al. proposed that progenitor cells positive for nestin - a stem/progenitor cell marker of the nervous system - are localized in vascular walls, where aSMA-positive vascular smooth muscle cells and pericytes function as the progenitors of Leydig cells [2]. They showed that these progenitor cells protrude from the vessel walls, accumulate in the vicinity of the vessel walls, and form Leydig cell clusters; these processes are accompanied by a loss of immunoreactivity toward aSMA. Heterogeneous populations of aSMA-positive peritubular spindleshaped cells form an integral and multifunctional component of the mammalian testis. These cells collaborate with Sertoli cells in the production and deposition of extracellular matrix element, resulting in the formation of tubular structures, with no evidence of typical Leydig cell characteristics [6]. On the other hand, a few peritubularly located spindleshaped cells are considered as a precursor cell of Leydig cell, because they showed expression of $3 \beta$-HSD and luteinising hormone receptor [15] and inhibin [18]. On the basis of previous literature and our finding, we think that immunoreactivity of tumor cells towards aSMA, inhibin, S-100, and nestin in our mouse reflects a dedifferentiation of Leydig cells. This hypothesis is supported by the fact that nestin has been found in a subset of peritubular spindle-shaped cells and in a population of normal and reactive Leydig cells [9].

Differential diagnosis include the theca cell tumor resembled their ovarian counterpart and myofibroblastic tumor. In humans, testicular theca cell tumor contains fusiform cells without lipid deposition which are arranged into fascicles or a storiform pattern in collagenized stromal tissues with numerous small vessels; the tumor cells are positive to aSMA and vimentin, and occasionally to S-100, but not reactive to inhibin [12]. Myofibroma is a benign mesenchymal neoplasm of myofibroblastic origin. In an infantile case, biphasic growth pattern is identified: (1) fascicles of myoid-appearing spindles cells with expression of aSMA, and (2) diffuse growth of primitive-appearing cells with vesicular nuclei and mitotic figures, which are focally arranged around hemagiopericytoma-like vasculatures [4]. Inflammatory pseudotumors are characterized by the proliferation of myofibroblastic spindle cells arranged in interlacing fascicles and whorls that sometimes display storiform patterns, accompanied by diffuse, but variably dense mixed inflammatory infiltrates throughout the lesion [11]. In both type of myofibroblastic tumors, spindle-shaped tumor cells show immunopositivity for aSMA but no reactivity for S100. There is evidence that nesin expression has been identified in reactive myofibroblasts [1] and in tumor cells of leiomyosarcoma [13]. Therefore, we can not rule out the possibility that spindle-shaped cells in our mouse displayed an intermediate cellular differentiation of myoid and Leydig cell phenotypes.

The tumor in our mouse mainly consisted of spindleshaped neoplastic Leydig cells with or without lipid deposits and with varying degrees of immunopositivity for inhibin, S-100, vimentin, and nestin. The presence of certain populations of aSMA-positive spindle cells indicate dedifferentiated Leydig cells rather than incompletely differentiated SCST cells. In conclusion, these findings suggest that the tumor in our mouse is most probably a malignant spindlecell-type Leydig cell tumor. Nonetheless, additional studies are required to better understand the occurrence of spindlecell type tumors in the testis.

ACKNOWLEDGMENT. We are very grateful to Chizuko Tomiyama, Takako Kazami, Yukie Jibiki, Haruka Miura, and Kayoko Iijima for their assistance in tissue preparation and staining.

\section{REFERENCES}

1. Aust, S., Jäger, W., Kirschner, H., Klimpfinger, M. and Thalhammer, T. 2008. Pancreatic stellate/myofibroblast cells express G-protein-coupled melatonin receptor 1. Wien. Med. Wochenschr. 158: 575-578.

2. Davidoff, M.S., Middendorff, R., Enikolopov, G., Riethmacher, D., Holstein, A.F. and Müller, D. 2004. Progenitor cells of the testosterone-producing Leydig cells revealed. J. Cell. Biol. 167: 935-944.

3. Emerson, R.E. and Ulbright, T.M. 2007. Morphological approach to tumours of the testis and paratestis. J. Clin. Pathol. 60: $866-880$.

4. Fine, S.W., Davis, N.J., Lykins, L.E. and Montgomery, E. 2005. Solitary testicular myofibroma: a case report and review of the literature. Arch. Pathol. Lab. Med. 129: 1322-1325.

5. Ge, R.S., Dong, Q., Sottas, C.M., Papadopoulos, V., Zirkin, B.R. and Hardy, M.P. 2006. In search of rat stem Leydig cells: identification, isolation, and lineage-specific development. Proc. Natl. Acad. Sci. U. S. A. 103: 2719-2724.

6. Hoeben, E., Briers, T., Vanderstichele, H., de Smet, W., Heyns, W., Deboel, L., Vanderhoydonck, F. and Verhoeven, G. 1995. Characterization of newly established testicular peritubular and prostatic stromal cell lines: potential use in the study of mesenchymal-epithelial interactions. Endocrinology 
136: 2862-2873.

7. Japanese Association for Laboratory Animal Science (JALAS). 1987. Guidelines for animal experimentation. Exp. Anim (Tokyo) 36: 285-288, (in Japanese).

8. Kim, I., Young, R.H. and Scully, R.E. 1985. Leydig cell tumors of the testis. A clinicopathological analysis of 40 cases and review of the literature. Am. J. Surg. Pathol. 9: 177-192.

9. Lobo, M.V.T., Arenas, M.I., Alonso, F.J.M., Gomez, G., Bazán, E., Paíno, C.L., Fernández, E., Fraile, B., Paniagua, R., Moyano, A. and Caso, E. 2004. Nestin, a neuroectodermal stem cell marker molecule, is expressed in Leydig cells of the human testis and in some specific cell types from human testicular tumours. Cell Tissue Res. 316: 369-376.

10. Magro, G., Gurrera, A., Gangemi, P., Saita, A. and Greco, P. 2007. Incompletely differentiated (unclassified) sex cord/ gonadal stromal tumor of the testis with a "pure" spindle cell component: report of a case with diagnostic and histogenetic considerations. Pathol. Res. Pract. 203: 759-762.

11. Orosz, Z. and Besznyák, I. 1995. Diffuse inflammatory pseudotumor of the testis, the epididymis and the spermatic cord. Pathol. Oncol. Res. 1: 75-79.

12. Sesterhenn, I.A., Cheville, J., Woodward, P.J., Damjanov, I., Jacobsen, G.K., Nistal, M., Paniagua, R. and Renshaw, A.A. 2004. Sex cord/gonadal stromal tumors. pp. 250-258. In: World Health Organization Classification of Tumours. Pathology and Genetics of Tumours of the Urinary Syetem and Male Genital Organs (Eble, J. N., Sauter, G., Epstein, J. I. and Sesterhenn, I.A. eds), IARC Press, Lyon, France.

13. Shimada, S., Tsuzuki, T., Kuroda, M., Nagasaka, T., Hara, K.,
Takahashi, E., Hayakawa, S., Ono, K., Maeda, N., Mori, N. and Illei, P.B. 2007. Nestin expression as a new marker in malignant peripheral nerve sheath tumors. Pathol. Int. 57: 6067.

14. Tarján, M., Sarkissov, G. and Tot, T. 2006. Unclassified sex cord/gonadal stromal testis tumor with predominance of spindle cells. APMIS 114: 465-469.

15. Teerds, K.J., Rijntjes, E., Veldhuizen-Tsoerkan, M.B., Rommerts, F.F. and de Boer-Brouwer, M. 2007A. The development of rat Leydig cell progenitors in vitro: how essential is luteinising hormone? J. Endocrinol. 194: 579-593.

16. Teerds, K.J., van Dissel-Emiliani, F.M.F., De Miguel, M.P., de Boer-Brouwer, M., Körting, L.M. and Rijntjes, E. 2007B. Oncostatin-M inhibits luteinizing hormone stimulated Leydig cell progenitor formation in vitro. Reprod, Biol, Endocrinol. 5: 43.

17. Ulbright, T.M., Srigley, J.R., Hatzianastassiou, D.K. and Young, R.H. 2002. Leydig cell tumors of the testis with unusual features: adipose differentiation, calcification with ossification, and spindle-shaped tumor cells. Am. J. Surg. Pathol. 26: 1424-1433.

18. de Winter, J.P., Vanderstichele, H.M.J., Verhoeven, G., Timmerman, M.A., Wesseling, J.G. and de Jong, F.H. 1994. Peritubular myoid cells from immature rat testes secrete activin-A and express activin receptor type II in vitro. Endocrinology 135: 759-767.

19. Young, R.H. 2008. Testicular tumors - some new and a few perennial problems. Arch. Pathol. Lab. Med. 132: 548-564. 